\title{
Water exchange of three shallow Łęczna-Włodawa Lakes
}

\author{
Beata Ferencz ${ }^{1}$, Jarosław Dawidek ${ }^{2}$ \\ ${ }^{1}$ Department of Landscape Ecology and Nature Conservation, University of Life Sciences, Akademicka 13, 22-950, Lublin, Poland; \\ e-mail: beata.ferencz@up.lublin.pl (Corresponding author) \\ ${ }^{2}$ Department of Hydrology, University of Maria Curie-Skłodowska, Aleja Kraśnicka 2 cd, 20-718 Lublin, Poland; \\ e-mail: jaroslaw.dawidek@poczta.umcs.lublin.pl
}

\begin{abstract}
The research was carried out in three Łęczna-Włodawa lake-catchment systems, during the hydrological years 2007-2009. The observed lakes varied in terms of basin morphometry and catchment features. The hydrological functioning of the lakes resulted from three main factors: 1) storage capacity of the lake basin, 2) catchment area and relief, 3) human impact on water distribution. The vertical water exchange ratio in Lake Sumin was almost four-times higher than flushing time. In Lakes Rotcze and Syczyńskie horizontal water exchange, presented as flushing time was significantly higher than the vertical one.
\end{abstract}

Keywords: flushing time, lake basin, water budget elements, Łęczna-Włodawa Lake District

\section{Introduction}

A lake-catchment system is complex, and threedimensional. A continuous matter and energy circulation occurs in the system. The systems play an important role in supplying freshwater for domestic, agricultural, and industrial uses in many countries (Wang and Dou 1998; Wetzel 2001). Lake water quality is affected by many watershed characteristics including land use, soil type, surface geology, drainage area, topography, hydrology, and climate (D'Arcy and Carignan 1997; Maberly et al. 2003; Nõges 2009). Many studies have been carried out to explore the relationship between lake water quality and watershed land use (Rhodes et al. 2001; Bajkiewicz-Grabowska 2002; Kubiak 2003; Mankin et al. 2003; Twesigye et al. 2011). A major factor that influences lake functioning is the pace and quantity of water exchange. A domination of either vertical or horizontal water exchange determines water quality, both physico-chemical and hydro-biological. Water exchange of lake basins is understood as a difference between total input and output. A difference between precipitation and evaporation is defined as vertical water exchange, whereas a difference between inlet and outlet is known as horizontal (Choiński 2007; Bajkiewicz-Grabowska 2009).
Horizontal water exchange is usually determined by territorial factors, e.g. geological structure, relief, while vertical depends mostly on meteorological factors, e.g. temperature, wind, etc.

Ratios were also used to characterize both vertical and horizontal water exchange. The pace of vertical water exchange is usually presented using the intensity ratio, which is the proportion of the volume of annually evaporated water to the lake volume. The ratio of horizontal water exchange is defined as the proportion of the average annual water outflow to the lake volume. It can be presented as 'residence time', defined as the average time a particle of a conservative substance spends in a given volume, or 'flushing time' defined as average transit time of water (FT) - (Rueda et al. 2006; Obertegger et al. 2007). Previous studies showed that flushing time is significantly correlated to total nitrogen load (TN) delivered to the lake basin (Cole and Pace 1998).

\section{Methods}

Flow rates analysis, including genetic forms surface and underground - was carried out to estimate the influence of terrestrial factors. Water flows were measured once a month, from $1^{\text {st }}$ November 
2007 to $31^{\text {st }}$ October 2009, using a flow-meter Nautillus 2000. Daily water levels of streams were used to calculate the flow rates.

An estimation of the quantity of water budget elements is difficult, due to the unavailability of measurement methods (e.g. lack of evaporation measurements). A basic element of the water budget is precipitation. It was measured using Hellmann's pluviometer, which according to Chomicz (1976) leads to a systematic error, up to $19 \%$ of measured precipitation value (Bajkiewicz-Grabowska 1999). Unadjusted sums of precipitation, used in this study to calculate water exchange, are also commonly used for analysis (Soczyńska 1997). Evaporation from the lakes is also difficult to estimate. Variability of the ratio results from the lake area, shape, exposure to atmospheric influence and other factors. Evaporation calculated according to the Ivanov equation was used in this study. There are no gauging stations in Łęczna-Włodawa Lake District that measure lake evaporation value. The only IMGW meteorological station that measures total evaporation from the area (Włodawa) is located at the slopes of the Włodawa Hills. The distance from the area under study disqualified the data as unreliable.

\section{Study area}

The research was carried out in three ŁęcznaWłodawa lake-catchment systems (Fig. 1). Lake Rotcze is elevated 170.5 m.a.s.l. The lake catchment area is small, but the groundwater basin is much larger (Table 1). The lake basin is bottom-flat, with the lakeshore development coefficient amounting to 1.0. The north, west and southern part of the lake is surrounded by peat-bogs of various widths. The lakeshore vicinity is drained to the west, to the Lake Uściwierz catchment. A draining ditch, $1.2 \mathrm{~m}$ in width was dug at the beginning of the $20^{\text {th }}$ century. Its depth does not exceed 1 $\mathrm{m}$. Several years ago an eastern inlet to the lake was functioning. The ditch was filled up due to the expansion of the built-up area.

Lake Sumin is elevated 170 m.a.s.l. The shape of the lake basin is irregular and asymmetric, significantly deeper (circa $6 \mathrm{~m}$ ) in the southern part (Fig. 2).

The lake is the largest among the lakes under study (Table 1). This flow-through lake is drained to the north by a perennial stream and seasonally to the west by a bifurcating stream. The only outlet drains wetlands located in the southern part of the catch-

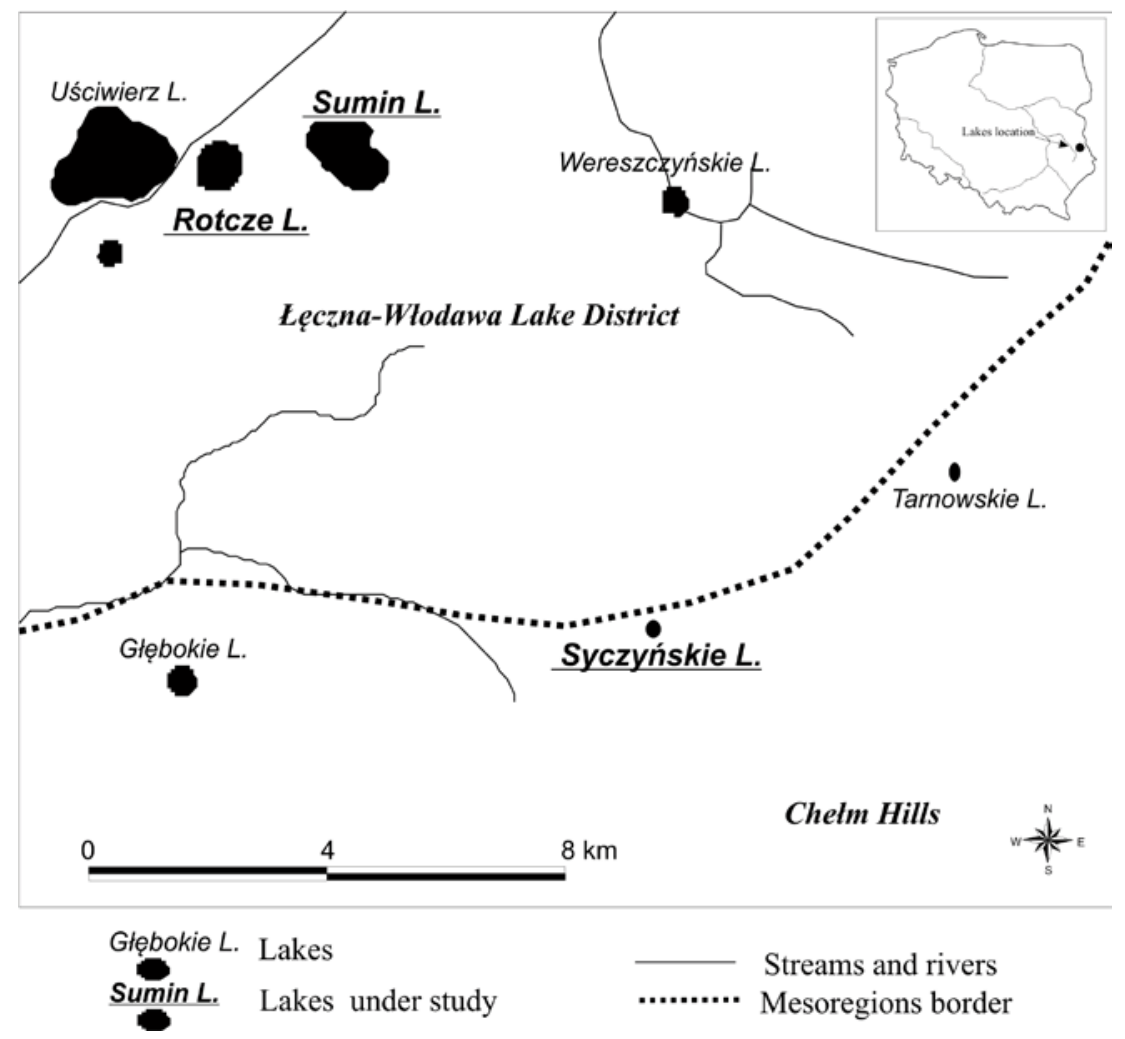

Fig. 1. Location of the lake-catchment systems under study 

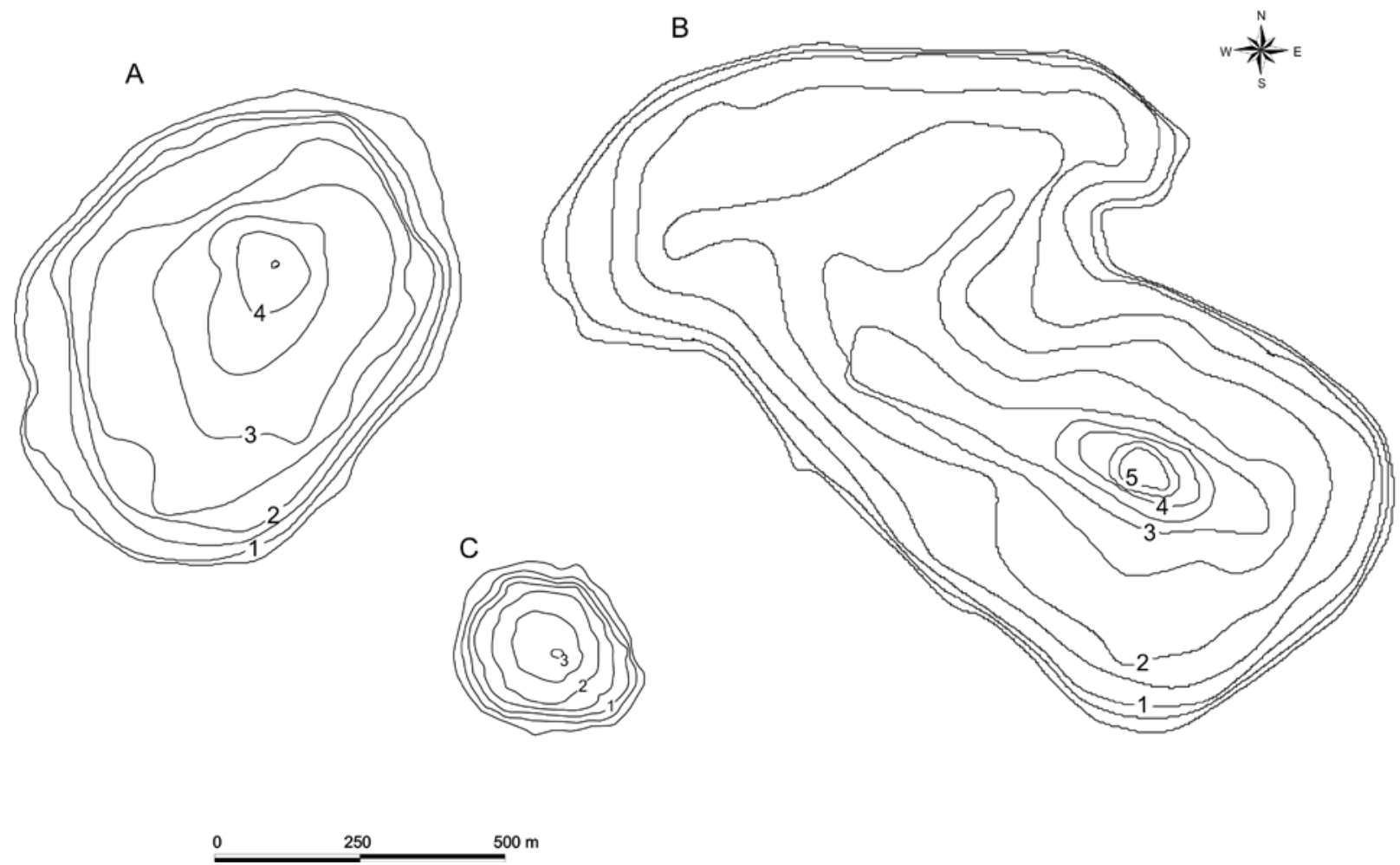

Fig. 2. Bathymetric charts of the lakes under study; A - Lake Rotcze, B - Lake Sumin, C - Lake Syczyńskie

Table 1. Selected characteristics of lake basins and catchments

\begin{tabular}{lrrr}
\hline \multicolumn{1}{c}{ Index } & Lake Rotcze & Lake Sumin & \multicolumn{2}{c}{ Lake Syczyńskie } \\
\hline Lake area [ha] & 47.30 & 105.85 & 7.40 \\
Lake volume [dam ${ }^{3}$ ] & 881.95 & 1922.20 & 95.50 \\
Length [m] & 884.60 & 1475.00 & 322.00 \\
Width [m] & 660.70 & 869.40 & 285.20 \\
Shoreline development coefficient & 1.00 & 1.30 & 1.00 \\
Depth [m] & 4.30 & 5.70 & 3.10 \\
Catchment area [ha] & 120.00 & 874.00 & 266.00 \\
Groundwater basin [ha] & 748.98 & 1134.26 & 266.00 \\
\hline
\end{tabular}

ment. Inlet flow ratio is low. During the period of increased water levels, the stream is restrained and backwater occurs, up to $100 \mathrm{~m}$. Any change of direction of the bifurcating stream depends on the lake water stage. The stream supplies the lake during the periods of normal and low lake water levels. During the periods of high water levels it plays the role of an outlet.

Lake Syczyńskie is one of the smallest ŁęcznaWłodawa Lakes. The shallow and circular lake basin was created among carbonate peat-bogs, on Cretaceous regolith (Borowiec 1990). The lake is elevated 179 m.a.s.l. and located in the south-west part of a catchment. This flow-through lake is fed by four inlets, one of which, originated from a spring, is perennial. The vicinity of mesoregional units of the Chełm Hills, as well as high hydraulic gradients favour lake supply with groundwater. A deep, perennial lake outlet directs drained water to the south, to the Swinka River. 


\section{Results}

Vertical water exchange. Extreme values of vertical water exchange (both maxima and minima) in Lakes Rotcze and Sumin were observed in 2009 $\left(115,000,-52,000\right.$ and $476,000,-157,000 \mathrm{~m}^{3}$, respectively). The highest alimentation of Lake Syczyńskie was observed in $2007\left(345,000 \mathrm{~m}^{3}\right)$, while the highest losses in $2008\left(-398,000 \mathrm{~m}^{3}\right)$. The highest amplitude of vertical water exchange was observed in Lake Rotcze, whereas the lowest in Lake Syczyńskie. Total volume of water, supplying Lake Rotcze during the time period under study due to vertical water exchange amounted to $16,700 \mathrm{~m}^{3}$. The deepest water exchange minima were noted in February and March 2009. The highest positive values in Lake Rotcze occurred in spring and summer while negative ones in winter (Fig. 3). A positive difference between precipitation and evaporation was also observed in Lake Sumin $\left(401,000 \mathrm{~m}^{3}\right)$. A significant disproportion of monthly water exchange values was observed. The highest alimentation (spring 2007, spring and autumn 2008 and summer 2009) was significantly higher than losses (Fig. 4). Vertical water exchange values in Lake Syczyńskie varied seasonally (Fig. 5). The highest values were observed in April and June 2007, June 2008 and May and July 2009. The lowest values occurred in winter of every year under study.

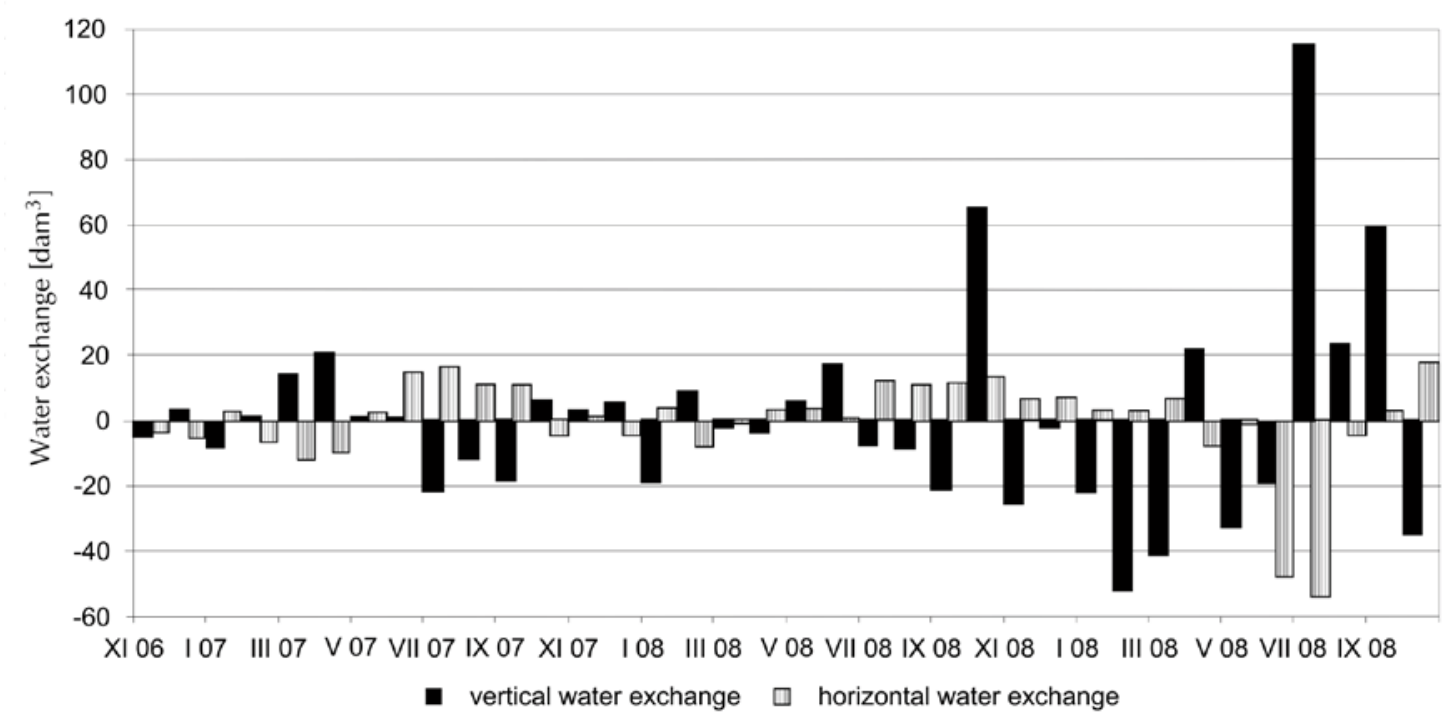

Fig. 3. Monthly water exchange of Lake Rotcze

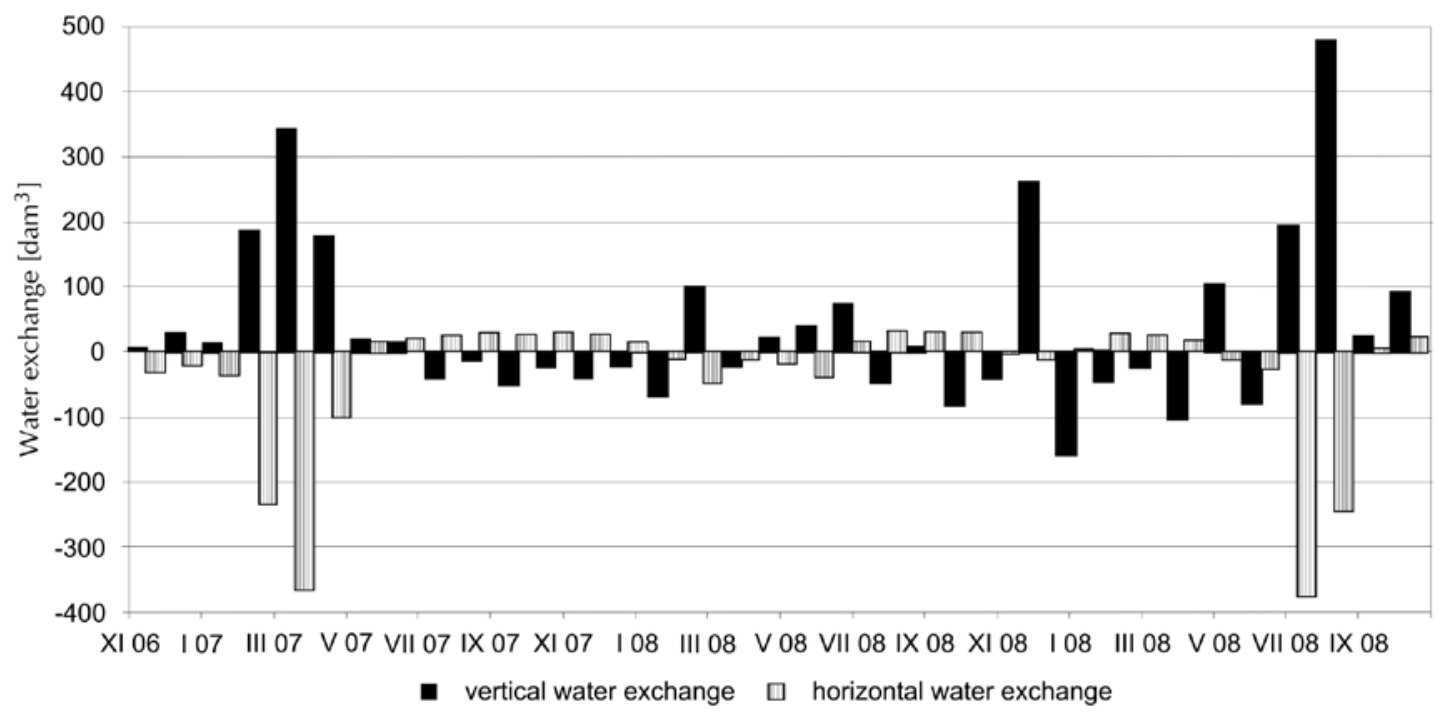

Fig. 4. Monthly water exchange of Lake Sumin 


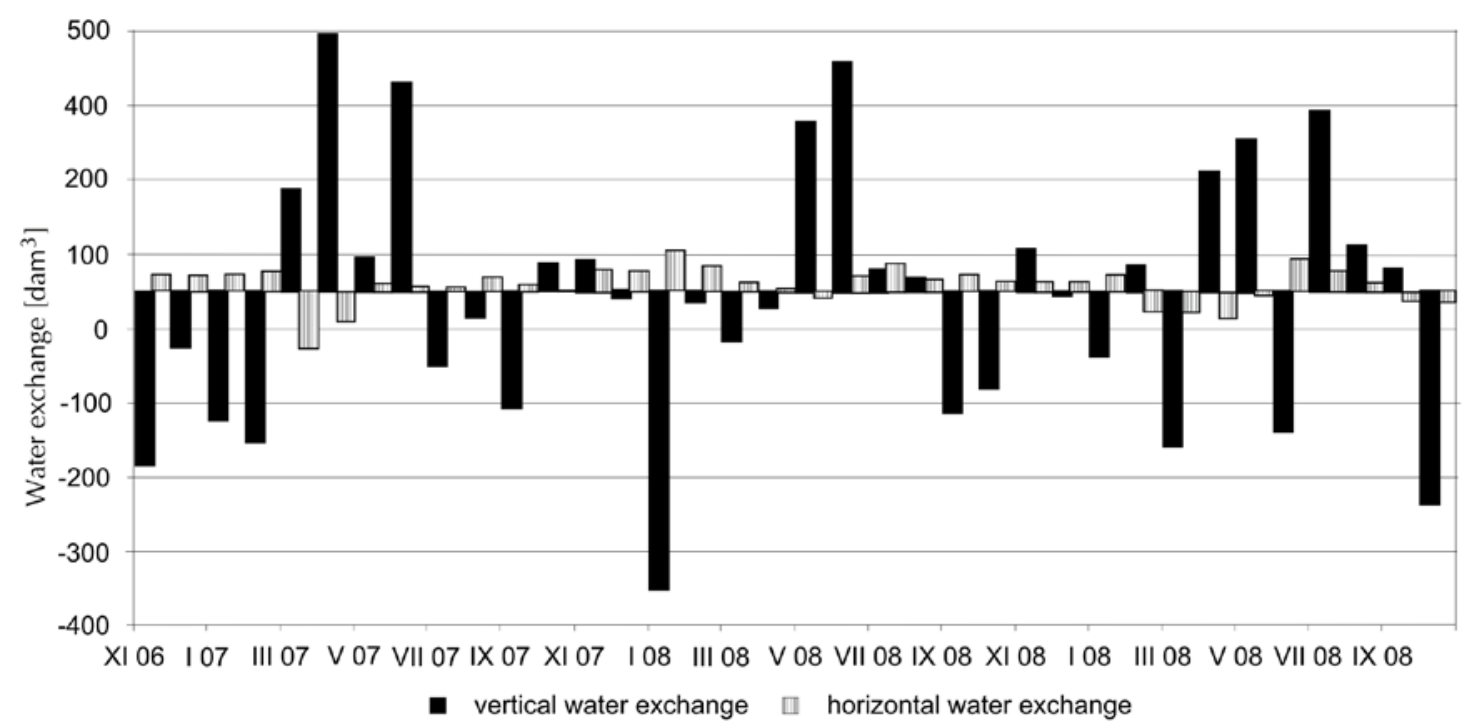

Fig. 5. Monthly water exchange of Lake Syczyńskie

Horizontal water exchange. Total horizontal water exchange of Lake Rotcze was characterized by the supremacy of the outflow. Individual features of horizontal water exchange were observed in each lake. The highest amplitudes were observed in Lake Sumin, while the lowest in Lake Rotcze. A positive water exchange in Lake Rotcze occurred in autumn and winter in 2007 and 2008 and in autumn 2009. Two equivalent minima occurred in winter 2007 and summer 2009, and smaller from January to May 2008. A seasonal changeability was observed only in Lake Syczyńskie. The highest values occurred in winter in 2007 and 2008, and in summer 2009. Minima were typical for the spring season.

The highest positive horizontal water exchange in Lake Rotcze was observed in January 2008. An increase of outflow fluvial activity was observed, similarly to Lake Sumin, in March 2007, May 2008, from February to April and in October 2009.

Exchange ratios. Exchange ratios were diverse in each lake under study. The highest rates were calculated in Lake Syczyńskie. The lake was shallow and intensively supplied with groundwater. The vertical exchange rate amounted to 2.9 year, while horizontal only 0.13 year. These values distinguished the lake among the group of Łęczna-Włodawa which is classified as super-passive. Slightly slower water exchange was observed in Lake Rotcze, which vertical exchange rate amounted to 3.8 year while horizontal one 0.97 year. The slowest pace of water exchange was observed in Lake Sumin. Vertical water exchange rate amounted to 4.02 year whereas horizontal 1.1 year.

Vertical-horizontal water exchange relations. Characteristic relations between vertical and horizontal exchange domination and variability were observed in all the investigated lakes. Vertical water exchange determined the functioning of the drained Lake Rotcze. The volume of water stored in the lake basin due to vertical water exchange was two times higher than that resulting from horizontal water exchange. An effective precipitation supply during the time period under study amounted to $16,700 \mathrm{~m}^{3}$ while losses due to an intense drainage amounted to $-10,700 \mathrm{~m}^{3}$.

A clear disproportion of water exchange elements were observed in Lake Sumin. Water levels were maintained due to vertical water exchange $(402,000$ $\mathrm{m}^{3}$ ), which equalized losses resulting from the lake draining $\left(-387,000 \mathrm{~m}^{3}\right)$. Lake Syczyńskie stood out among the lakes under study. Horizontal water exchange was significantly higher than vertical $(85,200$ $\mathrm{m}^{3}$ and $-96,700 \mathrm{~m}^{3}$, respectively).

\section{Discussion}

The issue of water exchange has very rarely been presented in the papers concerning ŁęcznaWłodawa Lakes. Among all the lakes under study only Lake Rotcze's flushing time is mentioned in the limnological literature. Lakes Sumin and Syczyńskie were never investigated from this point of view. A clear dif- 
ference in Lake Rotcze's flushing time presented in the literature and shown in this study should be pointed out. Choiński (1995), after Wojciechowski (1991) proposed to classify Łęczna-Włodawa lakes to the group of passive lakes. A difficulty in comparing results can be related to different methods of water exchange calculation. In this paper water exchange ratios, both vertical and horizontal, were calculated on the basis of systematic hydrological and limnological territorial measurements carried out in lake catchments. Many assumptions which were difficult to verify were made a priori in Wojciechowski's study. Lake outflows were calculated using the specific discharge of the Swinka River, while none of the investigated lakes was located in the Swinka River catchment. Underground outflow was estimated to be $50-55 \%$ (regardless of the water body). Lake volume was also considered as constant, with stable basin volume, accepted after Wilgat (1954).

Individual features of the pace and volume of water exchange were observed in Lakes Rotcze, Sumin and Syczyńskie during the time period under study. Flushing time was typically connected to the catchment area. The lowest flushing time was observed in a small, morphologically diversified catchment. Similar relations were presented by Michel (1992), DeWalle et al. (1997) and Wolock et al. (1997).

According to Lange (1986), Faraś-Ostrowska (1990), Jańczak (1991) and Choiński (1995), residence time of Polish lakes varies from 0.01 in Lake Trzebno to 88.5 years in Lake Piaseczno. The water of the majority of water bodies presented by Choiński (1995) exchanged horizontally faster than 10 years. Thus the lakes under study can be defined as average, which confirms Pasławski's (1975) classification.

Water shortages in Lake Rotcze, due to vertical water exchange in winter 2009, resulted from low precipitation in previous months (from November to February) and a relatively high temperature as well as many thaws during the winter. High temperatures and frequent rainfalls in summer 2009 favoured evaporation, especially from the saturated peat-bogs located near the lake shore. The high volume of Lake Sumin, elongated NW-SE, as well as the forest surrounding it, increased the lake's susceptibility to wind activity, hence decreased evaporation. The highest losses resulting from vertical water exchange were observed in December 2008. The mean temperature of the month amounted to $4.8^{\circ} \mathrm{C}$, which led to an increase in evapo- ration and sublimation. The monthly vertical water exchange of Lake Syczyńskie corresponded to monthly precipitation sums. Negative values, observed in January 2008 , followed a period of positive temperatures (circa $4^{\circ} \mathrm{C}$ ), which might have increased evaporation. Similar values were noted in October 2009. It was a period of high precipitation $(92 \mathrm{~mm}$ ) and temperatures (mean monthly temperature amounted to $14.2^{\circ} \mathrm{C}$ ). The diversity of horizontal water exchange of Lake Rotcze resulted from man-made water distribution changes. The depletion of the catchment area cut off the lake basin from a part of runoff from Garbatówka Hill. The deep ditch, which drained surface and hyporheic water resources, fed Lake Uściwierz, which is located further away. The geological structure of the shoreline vicinity hampered lake basin supply. The high rate of organic sediments (peat-bogs and alluvia) surrounding Lake Rotcze favoured storage capacity. Water was released only during the periods of long saturation (Borowiec 1990; Janiec 2002). The peat-bogs saturation occurred in 2009, when high precipitation was followed by intensive lake basin supply. In June and July the lake was supplied with over $100,000 \mathrm{~m}^{3}$ of water. The horizontal water exchange was negative during the time period under study. The minima were observed when streams were hydrologically most active (in February and March 2007 and in June and July 2009), which proved the role of the man-made decrease of the local base level (base level of streams). A ditch that directed water from Lake Sumin to the north was dug in the 1920s, crossing a watershed. Deepened in the 1950s the ditch facilitated catchment drainage to the Włodawka River basin. It disrupted the natural direction as well as the quantity and pace of water outflow. The highest-lying waterbody in the cascade-system of the Uściwierz Lakes was deprived of some of its water resources, which reduced its role as a supplier of the lower-lying Lake Rotcze.

It should be stressed that a dominance of atmospheric deposition in water exchange may be dangerous for trophy and maintaining the water quality of the lake. It was mostly visible during the periods of precipitation shortages. The dynamic water exchange of Lake Syczyńskie resulted from low basin volume, stability of groundwater supply (vicinity of the Chełm Hills), relief and catchment land use (increased runoff). 


\section{References}

Bajkiewicz-Grabowska E., 1999, Struktura fizycznogeograficzna układu krajobrazowego zlewnia-jezioro i jej wpływ na tempo naturalnej eutrofizacji jezior (Physical-geographical structure of lake-catchment landscape system and its influence on eutrophication processes), [in:] Zdanowski B., Kamiński M., Martyniak A. (eds), Funkcjonowanie i ochrona ekosystemów wodnych na obszarach chronionych (Functioning and protection of the aquatic ecosystems on protected areas), Wyd. IRS, Olsztyn: 77-84 (in Polish).

Bajkiewicz-Grabowska E., 2002, Obieg materii w systemach rzeczno-jeziornych (Circulation of matter in fluvial-lacustrine systems), Wydz. Geografii i Studiów Regionalnych UW, Warszawa, p. 274 (in Polish, English summary).

Bajkiewicz-Grabowska E., 2009, Water circulation in a lake at extreme water levels: Lake Wigry case study, Limnol. Rev. 9(2-3): 63-72

Borowiec J., 1990, Torfowiska regionu lubelskiego (Peatbogs of the Lubelszczyzna region), PWN, Warszawa, p. 348 (in Polish).

Choiński A., 1995, Wybrane zagadnienia z limnologii fizycznej Polski (Selected issues of physical limnology of Poland), Wyd. Nauk. UAM, Poznań, p. 298 (in Polish).

Choiński A., 2007, Limnologia fizyczna Polski (Physical limnology of Poland), Wyd. Nauk. UAM, Poznań, p. 547 (in Polish).

Chomicz K., 1976, Opady rzeczywiste w Polsce (Effective precipitation in Poland) (1931-1960), Prz. Geof. 21: 1925 (in Polish, English summary).

Cole J.J., Pace M.L., 1998, Hydrologic Variability of Small, Northern Michigan Lakes Measured by the Addition of Tracers, Ecosystems 1:310-320.

D’Arcy P., Carignan R., 1997, Influence of Catchment Topography on Water Chemistry in Southeastern Québec Shield Lakes, Can. J. Fish. Aquat. Sci. 54: 2215-2227.

DeWalle D.R., Edwards P.J., Swistock B.R., Aravena R., Drimmie R.J., 1997, Seasonal isotope hydrology of three Appalachian forest catchments, Hydrol. Process. 11: 895-906.

Faraś-Ostrowska B., 1990, Przyrodnicze uwarunkowania zróżnicowania przezroczystości wód wybranych jezior Pomorza (Natural conditions of water transparency diversity of selected lakes of Pomerania) [manuscript], Wydz. BGO UG, Gdańsk, p. 138 (in Polish).

Janiec B., 2002, Aktywność jonu hydroniowego w wodach torfowisk węglanowych pogranicza Polesia Lubelskiego i Pagórów Chełmskich (An activity of hydronium ion in waters of cretaceous peat-bogs of the border zone of Polesie and Chełm Hills), [in:] Radwan S., Gliński J., Geodecki M., Rozmus M. (eds), Środowisko przyrodnicze Polesia - stan aktualny i zmiany (Environment of the Polesie - actual state and changes), Wyd. PAN/O Lublin, Lublin-Szack-Brześć: 33-44 (in Polish).
Jańczak J., 1991, Fizycznogeograficzna typologia i ocena jezior na przykładzie Pojezierza Wielkopolskiego (Physical-geographical classification and assessment of lakes on the example of Wielkopolska Lake District), Mat. Bad. IMiGW, Ser. Hydrol. Oceanogr. 15: 1-157 (in Polish, English summary).

Kubiak J., 2003, Największe dimiktyczne jeziora Pomorza Zachodniego. Stan trofii podatność na degradacje oraz warunki siedliskowe ichtiofauny ( The Largest dimictic Lakes of Western Pomerania: Trophic status, susceptibility to degradation, and habitat conditions for fish fauna), Rozprawy ARSzcz. 214, Szczecin, p. 96 (in Polish, English summary).

Lange W., 1986, Fizyczno-limnologiczne uwarunkowania tolerancji systemów jeziornych Pomorza (Physico-limnologic conditioning of the Pomeranian lakes systems tolerance), Zesz. Nauk. UG, Rozpr. Monogr. 79, Gdańsk, p. 177 (in Polish, English summary).

Maberly S.C., King L., Gibson C.E., May L., Jones R.I., Dent M.M., Jordan,C., 2003, Linking nutrient limitation and water chemistry in upland lakes to catchment characteristics, Hydrobiologia 506-509: 83-91.

Mankin K.R., Wang S.H., Koelliker J.K., Huggins D.G., and de Noyelles F., 2003, Watershed-lake water quality modelling: Verification and application, J. Soil Water Conserv. 58 (4): 188-197.

Michel R. L. 1992, Residence times in river basins as determined by analysis of long-term tritium records, J. Hydrol. 130: 367-378. DOI:10.1023/ B:HYDR.0000008556.73832.75

Nõges T., 2009, Relationships between morphometry, geographic location and water quality parameters of European Lakes, Hydrobiologia 633: 33-43. DOI 10.1007/ s10750-009-9874-X

Obertegger U., Flaim G., Braioni M.G., Sommaruga R., Corradini F., Borsato A., 2007, Water residence time as a driving force of zooplankton structure and succession, Aquat. Sci. 69: 575-583. DOI 10.1007/s00027-007-0924-z

Pasławski Z., 1975, Typologia hydrologiczna jezior Pojezierza Wielkopolskiego (Hydrological typology of lakes of the Wielkopolskie Lake District), Prz. Geofiz., Prz. Geof. 20: 271-280 (in Polish, English summary).

Rhodes A., Newton R.M., Pufall A., 2001, Influences of land use on water quality of a diverse New England watershed, Environ. Sci. Technol. 35: 3640-3645.

Rueda F., Moreno-Ostos E., Armengol J., 2006, The residence time of river water in reservoirs, Ecol. Model. 191: 260-275.

Soczyńska U., 1997, Hydrologia dynamiczna (Dynamic Hydrology), PWN, Warszawa, p. 410 (in Polish).

Twesigye C.K., Onywere S.M., Getenga Z.M., Mwakalila S.S., Nakiranda J.K., 2011, The impact of land use activities on vegetation cover and water quality in the Lake Victoria Watershed, Open Environ. Eng. J. 4: 66-77.

Wang S.M., Dou H.S., 1998, Records of lakes in China, China Science Press, Beijing: 208-291. 
Wetzel R.G., 2001, Limnology. Lake and River Ecosystem, Academic Press, San Diego, p. 1006.

Wilgat T., 1954, Jeziora Łęczyńsko-Włodawskie (ŁęcznaWłodawa Lakes), Ann. UMCS B 8: 37-122 (in Polish, English summary).
Wojciechowski K., 1991, Powiązanie wód jeziornych z wodami powierzchniowymi i podziemnymi (Lake waters connections to surface- and groundwater), Stud. Ośr. Dok. Fizj. 19: 23-140 (in Polish).

Wolock D. M., Fan J., Lawrence G.B., 1997, Effects of basin size on low-flow stream chemistry and subsurface contact time in the Neversink River Watershed, New York, Hydrol. Process. 11: 1273-1286. 